\title{
Mother Tongue Education: A Quest of Quality and Access in Education
}

\author{
- Bishnu Kumar Khadka
}

\begin{abstract}
As it is claimed and is the ground reality that language is not everything but everything is nothing in education without language. Moreover, language shapes the learning and learning begins with language. In this regards, this article attempts to review the multilingual perspectives in terms of access and quality in education through mother tongue based education advocacy. It is theoretical in nature which is based on the secondary sources of theoretical review and tries to justify with policy and practice based rational for mother tongue education in Nepalese context.
\end{abstract}

Key words: Language, Mother Tongue, Access, Quality, and Education

\section{Background}

Language is fundamental to communication of all kinds, and it is communication that makes change and development possible in human society. Using - or not using - certain languages today can open a door, or close it, for large segments of society in many parts of the world (UNESCO, 2008, p. 2). For decolonizers language is a tool of domination (Awasthi, 2004; Bourdieu, 1977); for language groups it is a subjectivity and inter-subjectivity (Koirala, 2007); for utilitarian it is a vehicle to take people from the local to the global world (Khadka, 2007); for knowledge seekers and promoters it is a means to generate the hidden treasure of the subalterns' wisdom (Guha, 2005); for linguists it is a way to save language (Khadka et.al., 2006; Khadka, 2007); for activists it is a means to activate people (Yonjan, 2007); for existentialists language is the socio-political, cultural, and linguistic identity (CRED, 2005; Chirag, 2001), and for pedagogues it is a means to made easy and dignified learning (Mallikarjun, 2002). It means language is the response to the situatedness (Leve \& Wegner, 1992). To resolve these concerns one needs language of co-existence, reciprocal learning and teaching (Koirala, 2010, p. 30). 


\section{Mother Tongue Education: A Quest of Quality and Access in Education}

Nepal is a multilingual and multicultural country. The number of languages spoken in Nepal may actually be more than what the national census-2001 has reported above. Lewis (2009) recorded that 126 languages are spoken in Nepal. Among them, the majority of languages which are from the Tibeto- Burman language family are on the verge of extinction (S. Toba, I. Toba \& Rai, 2005). Likewise, Yonjan-Tamang (2005) argues that 144 languages are spoken within the territory of Nepal. However, a single language has been given power, recognition and prestige while, as a corollary, the remaining minority languages are impoverished and marginalized. (Yadav, 2013, p. 120). There are 123 languages spoken as mother tongue reported in census 2011. Nepali is spoken as mother tongue by 44.6 percent $(11,826,953)$ of the total population followed by Maithili $(11.7 \%$ 3,092,530), Bhojpuri $(6.0 \%$; 1,584,958), Tharu (5.8\%; 1,529,875), Tamang (5.1\%; 1,353,311), Newar (3.2\%; 846,557), Bajjika (3.0\%; 793,418), Magar (3.0\%; 788,530), Doteli $(3.0 \% ; 787,827)$, Urdu $(2.6 \% ; 691,546)$ (Census, 2011, p. 4).

The languages of Nepal fall into four language families: Indo- European (Indo- Aryan Nepali, Maithili, Bhojpuri, Tharu, Rajbamsi, Danuwar, Darai, Majhi, Bote and Kumale), SinoTibetan (Tibeto- Burman - Newari, Tamang, Magar, Gurung, Rai, Limbu, Sunuwar, Chepang, Dhimal, Pahari, Meche, Jirel, Thami, Thakalii, Raji, Raute, Hayu, Byasi, Lepcha, Sherpa, Manange, Kaike, Kham, Tibetan, Chantel, Kagate, Lhomi, Lhoke, Dolpa, Tchurong, Dura etc.), austro- Asiatic (Munda- Santhali or Satar) and Dravidian (Northern Kurux- Dhangar or Jhangar) (Bandhu, 1989, p.122). Nepal has more than hundred languages with 15 scripts (Khadka, Magar, \& Koirala, 2006; Koirala, Khadka, \& Magar, 2008). Muslim children for example should learn at least three scripts together, the Urdu, the Devnagari, and the English (Koirala, 2010, p. 30).

\section{Multilingualism and Language Teaching}

Even though Nepal is a multilingual and multiethnic country with 123 languages and more than 103 ethnic communities, children in most ethnolinguistic communities are deprived of basic education in their respective mother tongues. Uncertainty about the number of Nepal's languages and their reduced enumeration in last five censuses may be attributed to their lack of required information and awareness about mother tongues and also the 'one nation - one language' policy adopted during the Panchayat regime (Yadav, 2013, p. 124). Linguistic minorities are regarded as vulnerable. They communicate in their native tongues within their households and communities while they have to use Nepali as a lingua franca for wider communication. Their children are, however, too young to have elaborated proficiency in Nepali. Hence, when they start schooling they are thwarted and disadvantaged since they cannot compete with Nepalispeaking children who have acquired it as their mother tongue. Naturally, the children with mother tongues other than Nepali feel inferior, isolated, or incompetent and are forced to remain as a disadvantaged group in our school situation. 
Teaching in unfamiliar languages has hindered cognitive development in the children. Language not only helps promote equality and empowers people but also is a key factor for the social inclusion in ethno-linguistic communities. The children with mother tongues other than Nepali cannot compete with Nepali-speaking children who have acquired it as their mother tongue. Naturally, they feel inferior, isolated, or incompetent and are forced to remain as a disadvantaged group in our school situation (CDC, 2004, pp. 2-3). Many studies have already revealed that teaching in mother tongue in the early grades enhances children's ability to learn better than in second or foreign languages (UNESCO, 2003; Skutnabb-Kangas, 2003). It has also been reported that if children are taught in languages which are different from their home language, they drop-out from school, have low achievement and repeat classes due to a high failure rate. This state of affairs is still persistent in Nepal (Yadava, 2007; Awasthi, 2004). Nepali is the only official language and a lingua franca at the national level. Nepali and English have been occupying dominating roles in education for a long time.

\section{Mother Tongue Education}

The term 'mother tongue', though widely used, may refer to several different situations. Defining mother tongue is always controversial and difficult. A mother tongue of a preschool child will be a language the child actually speaks (Gupta, 1997). It has been defined as the first language learned at home during childhood, i.e. language acquired by birth (Phyak, 2007, p.342). Definitions often include the following elements: the language(s) that one has learnt first; the language(s) one identifies with or is identified as a native speaker of by others; the language(s) one knows best and the language(s) one uses most. 'Mother tongue' may also be referred to as 'primary' or 'first language'. The term 'mother tongue' is commonly used in policy statements and in the general discourse on educational issues. The language of instruction in school is the medium of communication for the transmission of knowledge. This is different from language teaching itself where the grammar, vocabulary, and the written and the oral forms of a language constitute a specific curriculum for the acquisition of a second language other than L1.

Learning another language opens up access to other value systems and ways of interpreting the world, encouraging inter-cultural understanding and helping reduce xenophobia (UNESCO, 2011, p.11). Mother tongue instruction generally refers to the use of the learners' mother tongue as the medium of instruction. Additionally, it can refer to L1 as a subject of instruction. It is considered to be an important component of quality education, particularly in the early years. The expert view is that mother tongue instruction should cover both the teaching of and the teaching through this language (ibid). Many children speak a home language that differs from the language of instruction in education programmes. Research confirms that children learn best in their mother tongue as a prelude to and complement of bilingual and multilingual 


\section{Mother Tongue Education: A Quest of Quality and Access in Education}

education (UNESCO, 2008, p. 6). Children in remote rural areas, who speak a different language at home, often have the biggest problems in trying to learn the school language with which they have no contact outside of school. This is a significant contributing factor to poor education quality, low literacy outcomes and high drop-out rates in many countries. It has been estimated that $50 \%$ of the world's out-of-school children live in communities which use a different language to the one used in the local schools.

The use of mother tongues in education impacts positively on children's attendance and performance in school (UNESCO, 2008, p. 3). Despite increasingly overwhelming evidence of the value and benefits of early education in mother-tongue, few countries invest in it. Designing policies to incorporate these findings should be central to addressing the low quality of education in the developing world. It also goes to the heart of making education more inclusive and ensuring the right to education for all. Many education systems favour using national or 'global' languages instead of mother-tongue teaching. Education is often carried out in the old colonial language, or an international language, such as English.

\section{Mother-Tongue Education: Quality and Access in Education}

At the World Conference on Education for All in Jomtien, Thailand in 1990, the international community committed to ensuring the universal right to education for "every citizen and every society", with developing countries making constitutional commitments to provide universal primary education for all (World Declaration on Education For All 1990, pp. 6-7). But as the 2015 deadline for achieving the six goals of the Education for All (EFA) conference draws closer, many countries are not on track to achieving the wide range of individual and development targets set out in Jomtien and reaffirmed in Dakar, Senegal in 2000 (EFA Summary Report 2010, p. 4). The initial response to removing barriers to basic education was improving access to schooling, which was taken to mean increasing the numbers of schools and teachers and then getting as many children into schools as possible (Dyer, 2002, p. 419). Various studies have shown that meeting a minimum of standards, including improving school facilities, having teachers who are sufficiently trained and have a mastery of content and pedagogy and, the focus of this paper, having appropriate language strategies, can significantly improve educational quality (EFA 2005, pp. 43-45).

Dakar Framework for Action $(2000$, p. 8$)$ recognises the need to tailor primary education to reach those belonging to ethnic minorities to make education contextually located and locally accessible. Learners who understand the language they are instructed in are more likely to engage meaningfully with content, question what they do not understand and even enjoy the challenge of new things. The Summer Institute of Linguistics (SIL) notes that people learn best when they are taught in a language they understand well (2006, p. 3). Most supporters of mother tongue-based learning are agreed that a child's home language can effectively be 
used as a language of instruction in the early years of their schooling as a bridge to learning a foreign language.

Mother tongue based education especially benefits disadvantaged groups, including children from rural communities (Hovens, 2002), and girls, who tend to have less exposure to an official language and tend to stay in school longer, achieve better, and repeat grades less often when they are taught in their mother tongue (UNESCO Bangkok, 2005). Most developing countries are characterized by multilingual societies yet foreign languages of instruction pervade a majority of education systems. A system where instruction is carried out in a language children do not speak is referred to as submersion, as it is comparable to forcibly holding a child under water (Skutnabb-Kangas 2000, p.105). However, research has shown that mother tongue-based schooling significantly improves learning (Benson 2004b; Trudell 2005; SIL 2006; UNESCO 2006; Kosonen 2009; Young 2009). The use of a familiar language to teach children literacy is more effective than a submersion system as learners "can employ psycholinguistic guessing strategies" to learn how to read and write (Benson, 2004a, p. 1).

\section{Mother Tongue Education in Nepal}

Nepal along with the nations of the world expressed its commitment for Education for All (EFA) by the year 2015. The policy makers have become aware that the EFA goals could not be achieved unless the mother tongues are employed as the instructional medium at the early basic education. It is expressed, explicitly, in Nepal's EFA National Plan of Action (2003). The same spirit is reflected on the National curriculum framework (2005) and School Sector Reform Plan (2009). The government of Nepal has also promulgated a crucial document for the implementation of mother tongue-based multilingual education (MTB MLE) program in Nepal; The Multilingual Education Implementation Guidelines (2010) etc. Showing its commitment towards various international conventions (Universal Declaration of Human Rights-1948; Jomtien World Conference on Education for All (EFA)- 1990; Dakar Framework of Action-2000; Millennium Development Goals-2000 and UN Declaration on the Rights of Indigenous Peoples 2007) and national constitutional provision and policies (Interim Constitution of Nepal-2007; Three Year Interim Plan -2008; EFA Core Document-2004-2009; EFA National Plan of Action-2003; Tenth Plan-2002-2007 and National Curriculum Framework for School Education in Nepal (NCF) - 2007, the government has just finished piloting MTMLE - a part of EFA programme - in financial collaboration with the Finish Government since January 2007 in eight languages and in seven schools of six different districts (Multilingual Education in Nepal: Hearsay and Reality, 2012, p.13). The National Educational Planning Commission (NEPC, 1956), National Educational System Plan (NESP, 1971), National Languages Planning Recommendation Commission (NLPRC, 1994), Nepal Education for All, National Plan of Action (NPA, 2003), National Curriculum Framework (NCF, 2005), School 
Sector Reform Plan (SSRP, 2009) and Multilingual Education Implementation Guidelines (2010) are some of the major policy documents to influence the educational language policies in Nepal.

The first modern school of Nepal, Durbar School, was an English medium school that was established in 1854 for the children of ruling Ranas. The focus shifted towards Nepali as the medium of education, during the Panchyayat and ultimately towards the mother tongues of the nation after the restoration of multiparty political system in 1990. However, the policies for the language of instruction after the commitments of the Government of Nepal to the World Declaration of Education for All (1990) and Dakar Framework of Action (2000) are, significantly, directed towards the quality of education. Nepal has agreed to apply the policy of mother tongue instruction in order to achieve its educational goals.

The report of National education planning commission (NEPC, 1956) developed a foundation for educational system of Nepal. The members of the commission traveled throughout the country and collected people's opinion for and against mother tongue as instructional medium. Mother tongue instruction could enhance the literacy development, maintain social harmony among the language groups and the government would earn credit were among the arguments given for employing the mother tongue instruction for school education. On the other hand, the educationists suggested the committee to recommend Nepali, national language, as the language of instruction because the mother tongues did not possess dictionaries, grammar and producing textbooks in these languages was difficult and expensive. Similarly, it was suggested that almost everyone could understand Nepali as it was the official language and lingua franca at the national level. The commission recommended that the Sanskrit and English medium of education could not satisfy the need of rural people and Nepali should be employed as medium of instruction from primary school up to university level. The report of NEPC has been criticized as the manifestation of one language construct. The commission placed emphasis on the universalization of primary education and on the improvement of service delivery systems across the country. But, the report failed to recognize the need for multilingual education in Nepal. Instead, the report placed emphasis on introducing reduction of multilingualism (Awasthi, 2004, p. 34).

The report of All Round National Education Committee (ARNEC) and New Education System Plan (NESP) also favored Nepali as the sole medium of instruction for school education. The ARNEC (1961) recommended that in every primary and secondary schools Nepali should be employed as the medium of instruction, except for language subjects. NESP (1971) contributed to establish Nepali as the single language to be employed as the language of instruction in the schools of Nepal. Most of the educational language policies developed during the Panchyayat regime focused on the use of Nepali and proclaimed linguistic nationalism. The Nepali 
language became a part of the nationalistic movement across the country (Awasthi, 2004). NESP (1971) recommended Nepali as the medium of instruction for primary and secondary education. However, it was recommended that the teachers could use local languages to explain lessons if the children could not understand Nepali language.

The advocacy of mother tongue education in Nepal began after 1990. The major reason behind mother tongue education include helping children learn by breaking barriers of language in the school and preserve and promote endangered languages through education (Phyak, 2007, p. 341). The constitution of Nepal (1990) not only recognized the native mother tongues as national languages but also clearly stated that language communities should have a right to operate mother tongue schools up to primary level (grade 5). National Languages Policy Recommendation Commission (Yadava \& Grove, 1994) addresses the language problems in Nepal in the context of constitutional recognition to the national languages, mother tongues. It recommended to begin language planning for the development of national languages and to employ them on education as instructional medium as well as to identify the possible domains for the national languages. Mother tongue schools up to primary level shall be opened in the areas where there are monolingual students (Yadava \& Grove, 1994, p. 37).

In Nepal, monolingual policy was adopted and practiced for long time. Because of monolingual policy, some of the indigenous languages are dead now and many of them are on the verge of extinction. So, in our context, three languages should be used for all purposes including teaching and learning. People should have the rights to use three languages everywhere either in office or in academic institution or in court or in media or in legislation. In the three languages, the first language is mother tongue, the second language is Nepali used as national lingua franca and the third language is English used as an international lingua franca (Rai, 2013, p. 234). For teaching and learning two types of modality can be adopted in our case. First modality deals with any language with mother tongue, Nepali as national lingua franca and English as international lingua franca. Second modality deals with Nepali as mother tongue, any indigenous language (if anyone wants to learn) as an additive language and English as an international language (ibid). In case of Nepal, the use of mother tongue in education assumes greater urgency and importance since most of the minority languages are in the verge of extinction owing to the lack of their use, literate traditions, and so on (Phyak, 2007, p. 346).

The best medium for teaching a child is his mother tongue or any other language a child understands well. The mother tongue is the natural means of self-expressions of the experiences and thoughts learnt in childhood (UNESCO, 1953). It is, therefore, significant to select their mother tongue as the medium for teaching the children. Teaching the children through mother tongue at the primary level is very significant to make the education accessible to the children and to involve them in the learning process (Dhakal, 2013, p. 24). 


\section{Conclusion}

Some argue that just changing the language of teaching will not solve all the problems of an education system. However, a change in the medium of instruction also brings about other changes. It makes the home culture visible, it allows learners to talk about their prior knowledge and experience and link them to new information, it brings the home and the school closer together, it opens up communication between families and teachers, it facilitates communication and participation in the classroom, it helps learners gain self-esteem and a stronger sense of identity... in sum, using the learner's language goes a long way toward resolving many of the access and quality issues that would lead us closer to reaching Education for All goals (UNESCO, 2008, p. 4). Educational administrators and managers understood language as a subject. Teachers on the other have used language as medium of instruction. Linguists and language activists understood language as rights of the people to learn in their mother tongues.

\section{References}

Awasthi, L. D. (2004). Exploring monolingual school practices in multilingual Nepal. Unpublished PHD Thesis. Danish University of Education, Copenhagen, Denmark.

Bandhu, C. M. (2009). Strategies for teaching mother tongues in Nepal. In Nepalese Linguistics, Vol. 24, pp. 1-10. Kathmandu.

CRED (2005). Mother tongue intervention at primary level. Kathmandu: Author.

CERID. (2005). Mother Tongue Intervention at Primary Level: A Study Report http://www. doe.gov.np/download/download_933981270.pdf [accessed 4/17/12].

CERID (2006). Situation of inclusive classroom in Nepal: Study report 10, EFA 2004-2009 (FRP): Balkhu Kathmandu: TU.

Department of Education. (2009). Report on MLE policy and strategy. Bhaktapur, Nepal: Ministry of education, Government of Nepal.

Ghimire, L. (2011). Ideologies in the educational language policies of Nepal. In Nepalese linguistics. Vol. 26, pp.: 36-44.

Government of Nepal. (1956). The report of national education policy commission. Kathmandu: Government of Nepal

Government of Nepal. (1961). All round national education commission. Kathmandu: Government of Nepal.

Government of Nepal. (1971). National education system plan. Kathmandu: Government of Nepal.

Government of Nepal. (1992). National education commission. Kathmandu: Government of Nepal

Government of Nepal. (1999). High level national education commission. Kathmandu: Government of Nepal. 
Government of Nepal. (2002). High level commission of education. Kathmandu: Government of Nepal.

Government of Nepal. (2003). Education for all: National plan of action. Kathmandu: Ministry of Education and sports, Nepal National Commission for UNESCO.

Government of Nepal. (2005). National curriculum framework for school education (Preprimary to 12) in Nepal.. Bhaktapur, Nepal: Curriculum Development Centre.

Government of Nepal. (2007). Interim constitution of Nepal. Kathmandu: Nepal Law Books Society.

Government of Nepal. (2009). School sector reform plan 2009-2015. 2009. Kathmandu: Ministry of Education.

Jones, N., Barnes, A. \& Hunt, M. (2005). Thinking through languages: A multilingual approach to primary school languages. In Language learning journal, Vol. 32, pp. 63-67.

Khadka, A., Chaudhary, T., Magar, K. J., Chaudhary, A. \& Pokhrel, R. (2006). Literacy in multilingual perspectives: Learning from Tharu, Tamang, Newar and Limbu language communities in Nepal. Kathmandu: World Education/ UNESCO Nepal.

Koirala, B. N., Khadka, A., \& Magar, K. J. (2009). Talking with Terai peoples of Nepal. In Press. Kathmandu: Office Support.

Koirala, B. N. (2010). Opportunities for Multi-Lingual Education in Nepal. In Journal of Education and Research Vol. 2, pp. 30-34.

Mallikarjun, B. (2002). Multilingual approach towards teaching in Indian schools. In Language in India: Strength for today and bright hope for tomorrow, 2(1). March 2002.

Ministry of Education. (2010). Multilingual education implementation guidelines, ms.

Ministry of Education. (2005). School level educational statistics of Nepal, ms.

Ministry of Education. (2005). School sector reform plan (2009-2015). The report of national languages policy recommendation commission (2007, trans Dubi Nanda Dhakal). Kathmandu: Central Department of Linguistics.

National Language Policy Recommendation Commission (2050 BS). Report of national language policy recommendation commission. Kathmandu: Prayanga Vabhavan.

Phyak, P. B. (2007). Mother tongue education: Practices and problems with reference to Limbu language. SNV: Nepal

Phyak, P. B. (2007). Mother Tongue Education: Judging from classroom pedagogy with reference to Limbu Language. In Nepalese linguistics: Linguistics Society of Nepal: Nepal .

Rai, I. P. (2013). Issues of language planning in Nepal: linguistic diversity, conflicts and peace building. In contribution to nepalese studies: Vol.40 No.2, pp. 217-38. CNAS: Kathmandu.

Rai, N. K. (Ed.) (2006). Nepalese linguistics. Kirtipur, Kathmandu, Nepal: Linguistic Society of Nepal. 
UNESCO. (1953). The use of vernacular languages in educations: The report of the UNESCO meeting of specialists (Paris): Monographs on Fundamentals Education.

UNESCO. (1953). The use of vernacular languages in education. Retrived from http:// unesdoc.unesco.org/images/0000/000028/0028 97EB.pdf (accessed in March 2010).

UNESCO. (1990). World declaration on education for all. Retrived from http://www.unesco. org/education/pdf/JOMTIE_E.PD (accessed in December 2011)

UNESCO. (2000). World education forum: The dakar framework for action. Retrived from http://unesdoc.unesco.org/images/0012/001211/121147e.pdf (accessed in March 2010).

UNESCO. (2003). Language vitality and endangerment. Document submitted to the International expert meeting on UNESCO program safeguarding of endangered languages: Paris.

UNESCO. (2007). Advocacy kit for promoting multilingual education: Including the excluded. Bangkok. UNESCO.

UNESCO. (2008). Improving the quality of mother tongue based literacy and learning. Kathmandu: UNESCO Kathmandu office.

UNESCO. (2011). Multilingual education in Nepal: Hearsay and reality. Retrived from http:// www.un.org.np/reports/multilingual-education. Accessed on January 2012.

World Bank. (2005). In their own language: Education for all. New York: World Bank.

Yadav, R. (1992). The use of the mother tongue in primary eduation: Nepalese context. In Contributions to Nepalese Studies S. Kathmandu: CNAS: Tribhuvan University.

Yadava, Y. P. (2007). Linguistic diversity in Nepal: Perspectives on language policy. Kathmandu: International Seminar on Constitutionalism and diversity in Nepal, CNAS, 22-24 August, 2007

Yadava, Y. P. (2013). Linguistic Diversity in Nepal Perspectives on Local Language Policy. In contribution to Nepalese studies: Vol.40 No.2, pp.119-42 : CNAS: Kathmandu. 